\title{
Aristoteles Mantığında ve İnformel Mantıkta Dolaylı Analoji Formlarına Dair Bir Sorușturma*
}

\author{
ZEYNEP ÇELIK \\ Kahramanmaraş Sütçü İmam Üniversitesi İlahiyat Fakültesi \\ zeynepcelik@ksu.edu.tr \\ https://orcid.org/0000-0001-9874-1058
}

\begin{abstract}
Öz
$\mathrm{Bu}$ çalışma, informel mantık alanındaki analoji formlarının yeniden yorumlanıp Aristoteles'in analoji teorisiyle harmanlanması sonucu ortaya çıkmıștır. Dolayısıyla çalışma Aristoteles'in analoji teorisiyle informel mantıktaki analoji teorisinin, teorik düzlemde karşılaştırılmasıdır. Çalışmadaki amacımız, Türkçe literatürde tek bir forma indirgenen analojik akıl yürütmenin, dolaylı analoji formları olarak nitelendirdiğimiz farklı formlarının olup olmadığının tespitine yönelik bir soruşturmadır. Bu noktada bizim iddiamız, batıdaki informel mantık çalışmalarında, indüktif, dedüktif ve a priori formları bulunan analojinin, Aristoteles'in de eserlerine dayanarak; paradigmatik, vaka temelli ve orantılı olarak ortaya konulabilmesinin ve bunların doğrudan analoji formlarından ayrıștırılmasının mümkün olduğudur.
\end{abstract}

Anahtar Kelimeler: Mantık, Akıl Yürütme, Analojik Akıl Yürütme, Paradigmatik Analoji, Vaka Temelli Analoji, Orantılı Analoji.

\section{An Inquiry into Forms of Indirect Analogy in Aristotelian and Informal Logic Abstract}

This study emerged as a result of reinterpreting analogy forms in the informal logic field blending it with Aristotle's analogy theory. Hence, it is the theoretical comparison of Aristotle's theory of analogy and theory of analogy in informal logic. Our aim in this study is to investigate whether there are different forms of analogical reasoning, which we describe as indirect analogy forms, which are reduced to a single form in Turkish literature. At this point, we claim that analogy, which has inductive, deductive, and a priori forms, can be put forward in a paradigmatic, case-based, and proportional manner, based on the works of Aristotle, in the western informal logic studies, and it is possible to distinguish them directly from analogy forms.

Keywords: Logic, Reasoning, Analogical Reasoning, Paradigmatic Analogy, CaseBased Analogy, Proportional Analogy. 


\section{Giriș}

İnsan, düşündüğünde bazı sonuçlara ulaşır. Bu sonuçlara ulaşmak için farklı akıl yürütme türleri kullanılır. ${ }^{1} \mathrm{Bu}$ akıl yürütme türlerinden bir tanesi de zaman zaman benzetim veya temsil olarak da ifade edilen analojidir (analogie). Analojik akıl yürütme, yapısal değerini de ortaya koyan Yunanca

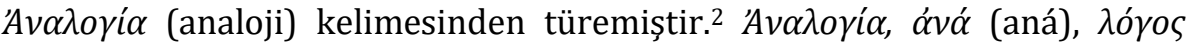
(logos) ve í $\alpha$ (-ia)'nın birleşiminden oluşan bir kelimedir. Ön ek olan aná, Hint-Avrupa kültüründe "üst" anlamında, logos kelimesi "oran" anlamında ve son ek olan ia "nitelik/kalite" anlamındadır.

Analojik akıl yürütme, kurucu unsurları arasında ortak bir ilişki örüntüsü paylaşan iki benzer şey arasında, benzerliğe dayalı çıkarım yapmaktır. Dolayısıyla analojik akıl yürütme genel olarak, iki şey veya olay arasındaki benzerliğe dayanarak, bunlardan birisi hakkında verilen bir hükmü diğeri hakkında da vermek, görülen ve bilinen benzerliklerden, görünmeyen ve bilinmeyen benzerlikleri ortaya çıarmak, ${ }^{3}$ ele alınan durumu, benzerliklerden faydalanarak yeni durumlarla ilişkilendirmek, nesneler arasında görünen ve daha önceden bilinen ortak noktalardan, görünmeyen ve önceden çıkarılmamış benzerlikleri ortaya çıkarmak, ${ }^{4}$ diğer bir ifade ile iki benzer şey arasında karşılaştırma yapmak şeklinde tanımlanmaktadır. Kısacası analojik akıl yürütmeye, kaynak olarak adlandırılan bir analogla, hedef olarak adlandırılan ikinci analog arasında benzerliğe dayalı kurulan ilişkidir diyebiliriz. ${ }^{5}$

Bütün akıl yürütme türlerinin olduğu gibi analojinin de bir formu (sureti) bir de içeriğí ${ }^{6}$ (maddesi) vardır. Analojik akıl yürütme, formu itibariyle

\footnotetext{
* Bu çalışma “Bir Akıl Yürütme Yöntemi Olarak Analojinin Değeri” isimli doktora tezimizden (Ankara Üniversitesi, Ankara, 2021) üretilmiștir.

${ }^{1}$ Klasik mantıkta genel olarak benimsenen eğilim, dedüksiyon, indüksiyon ve analoji olmak üzere üç tür akıl yürütme yöntemi olduğu yönündedir. Ancak özellikle informel mantık çalışmaları, farklı akıl yürütme yöntemlerinin de olduğunu göstermiștir. Bu konuda detaylı bilgi için bkz. Vedat Kamer, "Feshedilebilir Akılyürütme," Vedat Kamer ve Șafak Ural (ed.), VI. Mantık Çalıștayı Kitabı (İstanbul: Mantık Derneği Yayınları, 2016) içinde, ss.245-254; Vedat Kamer, "Aristoteles ve İnformel Mantık," Mehmet Mahfuz Söylemez ve Recep Duran (ed.), 2400'üncü Yllında Aristoteles ve Aristoteles'in Dünya Tefekküründeki Yeri (Lefkoşa: Yakın Doğu Üniversitesi Yayınları, 2017) içinde, ss.235-250; Vedat Kamer, "İnformel Mantık Açısından 'Akılyürütme' Kavramı Üzerine Bir Araştırma," (Yayımlanmamış Doktora Tezi, İstanbul Üniversitesi, İstanbul, 2014); Nazlı İnönü, "Yeni Bir Çıkarım Türü: Geri Çıkarım," (Yayımlanmamıș Doktora Tezi, İstanbul Üniversitesi, İstanbul, 2006).

2 Kelimenin kökü iki veya daha fazla șey arasındaki oranın kalitesini göstermektedir.

3 İbrahim Emiroğlu, Mantık Yanlışları (Ankara: Elis Yayınları, 2011), s.199.

${ }^{4}$ Zekai Șen, Modern Mantık (İstanbul: Bilge Kültür Sanat, 2003), s.42.

${ }^{5}$ Reinders Duit, "On The Role of Analogies and Metaphors in Learning Science," Science Education 75:6 (1991), s.650.

${ }^{6}$ Analojinin içeriği konumuzun sınırlarını aştığı için bu çalışmada değerlendirilmemiştir.
} 
dolaylı ve doğrudan olmak üzere tarafımızca ikiye ayrılmıştır. ${ }^{7}$ Doğrudan analoji ${ }^{8}$ iki şeyin doğrudan doğruya birbiri içinde erimesi (karışmasıayrıntıların benzeșmesi), dolaylı analoji ise, iki şeyin benzeyen yönlerinin karşılaştırılmasıyla, bu iki şeyin benzer olduğuna dair akıl yürütmek olarak tanımlanabilir. ${ }^{9}$ Bir analoji formunun dolaylı olabilmesi için öncelikle mantıksal ve formel açıdan çıkarım niteliği taşıması gerekir. Bunun dışında kaynak ve hedef arasındaki ilişkisel bağ belirli bir amaç doğrultusunda gerçekleşmelidir. $\mathrm{Bu}$ amaç doğrultusunda kurulmak istenen benzerlik ilişkisinde, kaynak ve hedefin belli olması çıkarımda ulaşılmak istenen sonucun da genellikle açık olmasına vesile olur. Doğrudan analoji formları ise genellikle bu özelliklerden bazılarını ya da hiçbirini taşımadıkları için dolaylı analojiden ayrılırlar. Ama çoğunlukla dolaylı analoji formları ile karıştırılmakta; hatta bazen dolaylı analoji olarak da kullanılmaktadırlar. Genel olarak doğrudan analoji formları için analojik akıl yürütmenin yardımcı unsurları diyebiliriz. Çünkü analojik akıl yürütme çoğu zaman doğrudan analoji formlarının yardımıyla elde edilir. Doğrudan analojinin birçok formu, dolaylı analojinin ise paradigmatik, vaka temelli ve orantı olmak üzere üç ayrı formu bulunmaktadır. Bu formlar, Aristoteles'in eserlerine ilaveten, informel mantık çalışmalarındaki analoji yaklaşımları ve hukuk alanındaki çalışmaların sentezi sonucu tarafımızca belirlenmiştir.

Dolaylı analoji formlarının daha iyi anlaşılabilmesi için aşağıda tarafımızca oluşturulmuş, analojinin formel ve içeriksel bir şeklini sunmaktayız. Bu çalışmada şekilde gösterilen formlardan yalnızca dolaylı analoji formları değerlendirilecektir.

\footnotetext{
7 Tarih boyunca yapısal, mantıksal ve pragmatik gerekçelerle analoji türleri ile ilgili çok çeşitli sınıflandırmalar yapılmıştır. Analojik akıl yürütme ile ilgili yapılan farklı sınıflandırmalar için bkz. Zeynep Çelik, "Bir Akıl Yürütme Yöntemi Olarak Analojinin Değeri," ss.92-97.

${ }^{8}$ Doğrudan analoji formları, çalışmanın kapsamını aştığı için detaylandırılmamıștır. Bu konuda detaylı bilgi için bkz. Çelik, "Bir Akıl Yürütme Yöntemi Olarak Analojinin Değeri," ss.58-73.

9 Doğrudan ve dolaylı analojinin tanımında, Piaget'in benzetme ile ilgili yaptığı tanımlardan esinlenilmiştir. Jean Piaget, Çocukta Dil ve Düşünme, terc. Sabri Esat Siyavuşgil (Ankara: Palme Yayıncllk, 2017), s.150.
} 


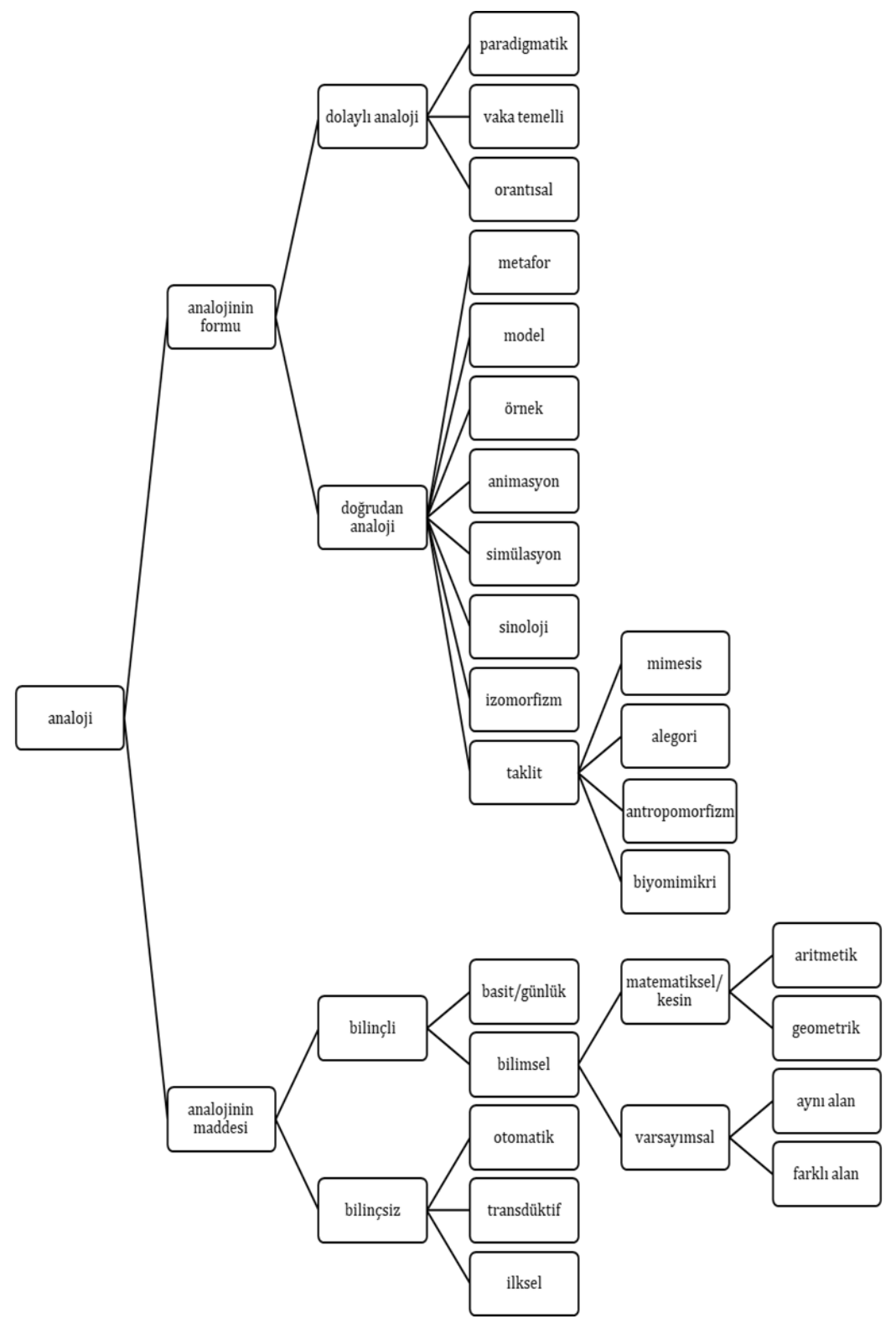

Şekil 1. Analojinin Formel ve İçeriksel Şablonu

Şekil 1'de de görüldüğü üzere çok çeşitli bağlamlarda değerlendirilen analojik akıl yürütme, özellikle informel mantıkta son zamanlarda çok tartışılan bir konu haline gelmiştir. Bu tartışmadaki en çetrefilli konular, 
farklı türde analojik akıl yürütme formlarının ${ }^{10}$ olup olmadı̆̆ı, bunların temelde indüktif veya dedüktif olarak veya tamamen farklı bir argüman kategorisi olarak kabul edilip edilmeyecekleri, herhangi bir gizli argüman veya eksik önerme içersin ya da içermesin, analojik akıl yürütmenin dedüktif veya feshedilebilir olmasının mümkün olup olmadığıdır. ${ }^{11}$ Biz bu çalışmada informel mantık çalışmalarına ek olarak Aristoteles'in de aslında analojik akıl yürütme formları ile ilgili satır aralarında söylediği çok önemli bilgiler ışığında, üç farklı analoji formu olduğunu ortaya koymaktayız. Bu sebeple çalışmamızda önce Aristoteles'in, ardından informel mantığın analoji teorilerini ele alıp, ardından dolaylı analoji formları olarak belirlediğimiz formları, iki geleneğin sentezi sayılabilecek bir yaklaşımla sunacağız.

\section{Aristoteles'in Analoji Teorisi}

Analojik akıl yürütme ampliatif ${ }^{12}$ bir çıkarım modeli olduğu için, Aristoteles mantığının kesinlik arayışında kendisine pek yer bulamamıştır. Çünkü geleneksel mantığın genel olarak analoji teorisi; "Eğer X ve Y bir takım ortak özelliklere sahipse, Y'de bulunan diğer özelliklerin X'de de bulunması muhtemeldir." gibi basit bir karakterdedir. Bu bakış açısı ne yazık ki, çoğu kez tüm analojilerin tek bir analizle ele alınabileceğini varsaymaktadır. Yani, yuvarlak benzetmelerin kareye uyması için zorlanması, güçlü ama karmaşık bir akıl yürütme biçiminin basitleştirilmesine sebep olmuştur. Diğer bir deyişle, analojiyi diğer akıl yürütme türlerinin standartlarına göre değerlendirmek; meşru benzetmelerin temelde kusurlu görünmesine neden olmuş ve analojinin tam anlamıla anlaşılmasını ötelemiştir. ${ }^{13}$ Dolayısıyla analojik akıl yürütmeyi anlamanın ilk adımı, çeșitli formları olduğunu ve farklı işlevleri yerine getirmek için kullanılabildiğini kabul etmektir.

Analojik akıl yürütmeyi sadece basit bir formdan ibaret görüp bu minvalde değerlendirenlerin görüşlerini şöyle bir örnekle gösterebiliriz: "Ayşe, Fatma ve Emine Karadenizliler ve renkli gözlüler, Beyza da Karadenizli, o halde muhtemelen Beyza da renkli gözlüdür."14 Bu hiçbir gerekçe göstermeden günlük hayatta yaptığımız basit bir çıkarım örneğidir.

\footnotetext{
10 İnformel mantık savunucuları bu formları argüman șemaları olarak değerlendirirler. Ancak bu çalışmada ortaya koyduğumuz iddia bunların analojik akıl yürütmenin farklı formları olduğu yönündedir.

${ }_{11}$ Manfred Kraus, "Arguments by Analogy (and What We Can Learn about Them from Aristotle)," Frans H. van Eemeren ve Bart Garssen (ed.) Reflections on Theoretical Issues in Argumentation Theory (Switzerland: Springer, 2015) içinde, s.171.

${ }^{12}$ Sonucun öncülleri aşması olarak tanımlanabilir.

${ }^{13}$ Bruce N. Waller, "Classifying and Analyzing Analogies," Informal Logic 21:3 (2001), s.199.

${ }^{14}$ Burada genetik yatkınlıkların hesaplandığı bir çıkarım da yapılabilir. 0 zaman sonucun doğru olma olasılığının arttığı bilimsel analoji yapılmış olur.
} 
Ancak çıkarımı destekleyecek hiçbir karine bulunmadığı gibi, kolaylıkla çürütülmesi de muhtemeldir. Bu örnek aynı "Falancada da aynı hastalık vardı, şu ilacı içti iyi oldu, sen de iç iyi gelir" diyen birinin yanıltıcı yönlendirmesine benzemektedir. Bizim bu çalışmada temellendirmeye çalıştığımız mesele aslında tam olarak analojik akıl yürütmenin, bu kadar basit bir çıkarım türü olmadığı, aksine farklı formlarının farklı işlevlerde kullanıldığı karmaşık bir çıkarım türü olduğudur.

Klasik mantığın analoji teorisini, Aristoteles'in analojiye bakış açısı şekillendirir. Aristoteles analojik akıl yürütme ile ilgili çok fazla açıklama yapmamıștır. Çünkü o sistemini dedüksiyonun en mükemmel șekli olarak tanımladığı kıyas (mantıki kıyas) üzerine kurmuştur. Dolayısıyla Aristoteles geleneğini devam ettirenler de analojiye karşı hep mesafeli olmuştur. Ancak Aristoteles'in analojik akıl yürütme ile ilgili detaya girmemesi, onu önemsemediği anlamına gelmemelidir. Nitekim araştırmamız göstermiştir ki aslında Aristoteles bize analojik akıl yürütme ile ilgili satır aralarında çok önemli bilgiler vermiştir. Öncelikle Aristoteles'e göre akıl yürütme yani istidlal yapabilmenin dört olmazsa olmaz şartı vardır ki bunlardan üçüncüsü farklılıkları dördüncüsü ise benzerlikleri algılama gücüdür:

Bize bol sayıda istidlâller temin edecek aletlere gelince, bunların sayısı dörttür: Birincisi, önermelerin elde edilmesi; ikincisi, bir bölümcül ifadenin kaç manada alındığını ayırt etme gücü; üçüncüsü, ayrımların keşfedilmesi; dördüncüsü ise özdeşliğin tahkikidir. $\mathrm{Bu}$ son üç alet de bir manada önermedir; çünkü onlardan her biri için bir önerme teşkil olunabilir. Söz gelimi seçilmesi gereken, kâh güzel, kâh hoșa giden, kâh faydalı olabilir, duyum kaybolduktan sonra tekrar bulunabilmesi bakımından ilimden farklıdır. Halbuki ilim tekrar ele geçirilemez. Nihayet sıhhatli sıhhate nazaran neyse, iyi olan da iyiliğe nazaran odur: Bu önermelerden birincisi, aynı terimin mana değişikliğinden; ikincisi, nesnelerin farklarından; üçüncüsü, benzerliklerinden çlkarılmıştır. ${ }^{15}$

Aristoteles'in de belirttiği gibi benzerlikleri ve farklılıkları algllama yeteneği, akıl yürütme yapabilmenin olmazsa olmaz iki bileșenidir. Dolayısıyla yeni bilgiler elde edebilmemiz için bu iki mekanizmanın kullanımı şarttır. Çünkü hayatımız boyunca karşılaştığımız hiçbir durum, önceden karşılaştığımız başka bir durumla tamamen aynı değildir. Bizim hayatta kalma ve öğrenme yeteneğimiz, geçmişte yaşadığımız ve şimdi karşılaştığımız durumlar arasındaki benzerlikleri ve farkları bulma,

${ }^{15}$ Aristotle, Topica, terc. E. S. Forster (Cambridge: Harvard University Press, 1960), 105a20-30. 
geçmişten elde ettiğimiz bilgiyi, deneyimi içinde yaşanılan an için kullanabilmemize bağlıdır. Analojik akıl yürütmenin değeri de aslında bu iki mekanizmanın değerinden gelmektedir.

Aristoteles'in eserlerinin dikkatli bir analizi bizi, analoji ile ilgili birçok bilgiye ulaştıracaktır. Örneğin, onun eserlerinden genel olarak analojik akıl yürütmede dört unsur bulunduğu anlaşılmaktadır. Nitekim Birinci Analitikler'de "Büyük terimin, üçüncü terime benzer bir terimle orta terime ait olduğu ispat edildiği zaman misal vardır. Ama orta terimin üçüncü terime, birincinin üçüncüye benzer terime ait olduğunun bilinmesi gerekir.",16 Retorik'te ise "Misal öyle bir istidlaldir ki, büyük terimin orta terim olduğu, küçük terime benzer dördüncü bir terimle tasdik edilir."17 ifadelerini kullanmıştır. Buradan Aristoteles'in aslında analojide dört unsur olduğuna işaret ettiği anlaşılmaktadır. Aristoteles'ten sonra analojik akıl yürütme formunu oluşturan dört unsur şu şekilde belirlenmiştir:

1- Benzetilen (Muşebbeh, Fer', Konu veya Hedef)

2- Kendisine benzetilen (Muşebbehu'n-bih, Asıl, Araç veya Kaynak)

3- Sebep (Illet, Ortak Vasıf): Hedef ile kaynak arasındaki bağı sağlayan unsur.

4- Benzetme (Sonuç, Hüküm) ${ }^{18}$

Yine Aristoteles'in eserlerine dayanarak, dolaylı analoji formlarına ulaşmak mümkündür. Çünkü Aristoteles, analoji için üç farklı anlama gelen üç farklı terim kullanmıştır. Bunlar paradigma ve örneklem anlamında kullandığı $\pi \alpha \rho \alpha ́ \delta \varepsilon \varepsilon \gamma \mu \alpha$ (paradigma) ${ }^{19}$; oran ve orantı anlamında kullandığ

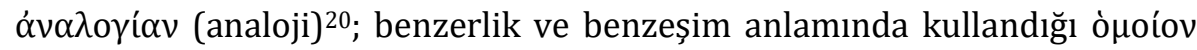

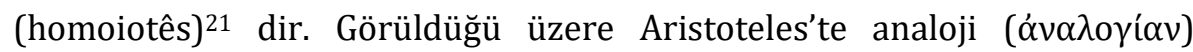
kelimesi, orantı analojisini ifade etmektedir.

Terimlerin kullanımlarına bakılacak olursa Aristoteles'in eserlerinde, analojik akıl yürütmenin üç farklı formu olduğu ve bunların kullanım

\footnotetext{
${ }^{16}$ Aristotle, Prior Analytics, terc. Hugh Tredennick (Cambridge: Harvard University Press, 1962) $68 \mathrm{~b} 40$.

${ }^{17}$ Aristoteles, Retorik, terc. Mehmet H. Doğan, (İstanbul: Yapı Kredi Yayınları, 1995), 1357b25.

${ }^{18}$ Halil İmamoğlugil, Klasik Mantıkta Akıl Yürütme (Ankara: Araștırma Yayınları, 2018), s.153; Necati Öner, Klasik Mantık (Ankara: Ankara Üniversitesi İlahiyat Fakültesi Yayınları, 1986), s.173.

${ }^{19}$ Bkz. Aristotle, Prior Analytics, 68b40-69a5-15, Aristoteles, Retorik, $1402 \mathrm{~b} 15$.

20 Bkz. Aristoteles, Metafizik, terc. Y. Gurur Sev, (İstanbul: Pinhan Yayıncılık, 2018), 1048b5, Aristoteles, Nikomakhos'a Etik, terc. Furkan Akderin (İstanbul: Say Yayınları, 2014), 1131a251131b5, Aristoteles, Poetika, terc. Ari Çokona, Ömer Aygün (İstanbul: Türkiye İş Bankası Yayınları, 2020), 1457b5, Aristotle, Posterior Analytics, terc. Hugh Tredennick (Cambridge: Harvard University Press, 1960), 98a20.

${ }^{21}$ Bkz. Aristotle, Rhetorica Ad Alexandrum, terc. H. Rackham (Cambridge: Harvard University Press, 1957), 1422b10-1422b35.
} 
alanlarının farklı olduğu söylenebilir. Çünkü Aristoteles, her bir formu farklı bir işlevi yerine getirmesi için kullanmıştır. Bu formları ve Aristoteles'in kullanım biçimlerini aşağıda teker teker açıklayacağımız için şimdi informel mantık çalışmalarındaki analojik akıl yürütme formlarına kısaca değinelim.

\section{2. İnformel Mantığın Analoji Teorisi}

Analojik akıl yürütmenin mantıksal yapısı, temelde bazı benzerliklerin varlığından, başka bir benzerliğin varlığına doğru akıl yürütmektir. Diğer bir deyişle analoji, iki sistemde de ortak olduğu belirlenen bir veya daha fazla özellikten yola çıkılarak bu iki sistemde başka bir özelliğin de muhtemelen her iki sistem için ortak olduğu sonucuna ulaștıran bir akıl yürütme olarak tanımlanabilir. Analojik akıl yürütme ile ilgili informel mantıkta en temelde şu şekilde bir ayırım söz konusudur:

Analojik akıl yürütme müstakil bir akıl yürütme midir?22

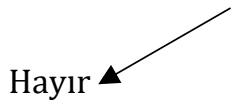

Bütün analojiler mecazi karakterdedir. Dolayısıyla sezgiseldir ve muhtemelen retorik fonksiyonlarından başka bir işlevleri yoktur.

(Allen, Kaptein, Agassi, Beardsley)

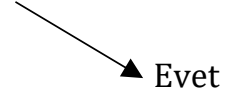

(A) İndüktif bir formdadır.

(Wreen, Govier, Waller)

(B) Dedüktif bir formdadır.

(Woods, Hudak, Waller)

(C) A priori bir formdadır.

(Barker, Guarini)

Burada ilk olarak analojik akıl yürütmeyi bir akıl yürütme türü olarak görmeyen eleştirmenlerin argümanlarını verip, daha sonra analojiyi müstakil bir akıl yürütme olarak kabul edenlerin görüşlerini sıralayacağız. Tablonun solundaki filozofları yani, analojik akıl yürütmeyi müstakil bir akıl yürütme yöntemi olarak görmeyenleri, iki gruba ayırabiliriz: Birinci gruptakiler, analojik akıl yürütme ile elde edilmeye çalışılan yeni durumun (hedef) zaten kaynak durumdan evrensel iddia yoluyla, dedüktif olarak çıkarıldığını iddia ederler. İkinci gruptakiler ise, analojinin doğası gereği yanıltıcı olduğu için herhangi bir çıkarım mekanizması olamayacağını iddia ederler. ${ }^{23}$

Analojik akıl yürütmenin, müstakil bir akıl yürütme türü olduğunu savunanlar da kendi aralarında farklı guruplara ayrılmaktadır. Özellikle

\footnotetext{
22 Şekil Botting'in makalesinden uyarlanmıștır. David Botting, "The Paradox of Analogy," Informal Logic 32:1 (2012), s.98.

${ }^{23}$ Botting, "The Paradox of Analogy," s.100.
} 
Govier, Waller ${ }^{24}$ ve Guarini, analojik akıl yürütmenin iki türünün olduğu konusunda hemfikirdir. Bu türlerden birincisi sonuçlarının geçici bir şekilde belirlendiği (yani "olası", "muhtemelen" gibi kelimelerle nitelendirilen) analojilerdir. Bunlar indüktif analojidir. Bu türden analojiler deneysel akıl yürütmelerde ve tartışmada kullanılır. ${ }^{25}$ İndüktif analojinin formu şu şekildedir:

1. A; $x, y, z$ özelliklerine sahiptir.

2. B de $x, y, z$ özelliklerine sahiptir.

3. A, fözelliğine sahiptir.

4. f özelliğine sahip olmak $x, y$, $z$ ile ilişkilidir.

5. Dolayısıyla, muhtemelen, B'nin f özelliği vardır. ${ }^{26}$

İkincisi, dedüktif analoji formudur. Günlük hayatta en sık kullandığımız bu analoji formu, bize göre aceleci bir genelleme sonucu elde edilmektedir. Genellikle karşıdakini ikna etmek için kullanılan dedüktif analojinin formu şu şekildedir:

1. A, x özelliğine sahiptir.

2. x özelliğine sahip olan her şey f özelliğine de sahiptir. (gizli tümel önerme)

3. $B$ de $x$ özelliğine sahiptir.

4. Dolayısıyla B de fözelliğine sahiptir.

Üçüncüsü, a priori analoji formudur. Waller bu analoji formunun dedüktif olduğunu iddia etse $\mathrm{de}^{27}$ genel olarak a priori veya mantıksal analoji ${ }^{28}$ olarak kullanılmaktadır. Çünkü bu formda iki şey karşılaştırılırken gizli bir tümel önerme yoktur. Onun yerine iki şey bir ilkeye göre karşılaştırılır ve bu ilkenin de a priori olduğu düşünülmektedir. Dolayısıyla a priori analojinin amacı iki şey arasında bir karşılaştırma yaparken, arka plandaki temel ilkeyi ortaya çıkarmaktır. ${ }^{29}$ Genellikle hukuk alanında benzer iki davayı karşılaştırırken ve tıpta tanı koymada kullanılır. A priori analojinin

\footnotetext{
${ }^{24}$ Bruce Waller, etik, hukuk ve metafizikte bulunan analojik argüman türlerinin dedüktif yeniden inşasını savunur ve bunları deneysel akıl yürütmede bulunan indüktif analojilerden ayırır. Waller, "Classifying and Analyzing Analogies," Informal Logic 21:3 (2001), ss.200-204.

${ }^{25}$ Bermejo-Luque, “A Unitary Schema for Arguments by Analogy," Informal Logic 32:1 (2012), s.22.

${ }^{26}$ Trudy Govier, "Analogies and Missing Premises," Informal Logic 11:3 (1989), s.141.

${ }^{27}$ Waller, "Classifying and Analyzing Analogies," ss.204-212.

28 Govier, "Analogies and Missing Premises," s.142.

${ }^{29}$ Trudy Govier, "Should A Priori Analogies Be Regarded as Deductive Arguments?," Informal Logic 22:2 (2002), s.155.
} 
formu şu şekildedir:

1. İkimiz de a durumuna katılıyoruz.

2. a'ya katılmanın en makul nedeni C ilkesinin ${ }^{30}$ kabul edilmesidir.

3. C ilkesi, b'yi ima eder (b, C ilkesine uyan bir durumdur).

4. Bu nedenle tutarlılık, b'nin de kabul edilmesini gerektirir. ${ }^{31}$

Aşağıda informel mantık çalışmalarındaki analoji formlarıyla birlikte Aristoteles'in analoji formlarını ima ettiği bazı pasajlar karşılaştırmalı olarak verilecektir.

\section{Dolaylı Analoji Formları}

Dolaylı analoji olarak belirlediğimiz formlar, paradigmatik, vaka temelli ve orantısal olmak üzere üçe ayrılmaktadır. Paradigmatik analoji formu, Aristoteles'in paradigma kelimesini kullandığı pasajlardaki yaklaşımından esinlenerek oluşturulmuş, vaka temelli analoji formu vakıa hukuku (common law) sistemindeki vaka temelli akıl yürütme (case based reasoning) yaklaşımından esinlenerek oluşturulmuştur ve orantısal analoji formu ise birçok çalışmada kullanılan orantıya dayalı analojidir. Bu üç form farklı işlevleri yerine getirmek için kullanılsalar da hepsinin ortak noktası, öncüller arasında mantıken geçerli bir ilişki kurarak aradaki illet bağı vesilesiyle sonuç önermesinin elde edilmesidir. Şimdi sırasıyla bu formları ele alarak çalışmamızı temellendireceğiz.

\subsection{Paradigmatik Analoji Formu}

Paradigmatik analoji, ${ }^{32}$ iki tekilin aynı cinste mündemiç olduğu durumlarda, tekilden tekile giden bir akıl yürütme formudur. ${ }^{33}$ Diğer bir deyişle, iki tekilin ortak özellikleri (genellikle ortak hassaları) vasıtasıyla, ortak bir tümel çatısında karşılaştırıp birinde olan bir özelliğin diğerinde de olabileceğini varsaymaktır. İki şeyin paradigmatik olarak karşılaştırılması genellikle ortak özelliklere göre yapılır.

Aristoteles analojinin en çok paradigmatik formundan bahsetmiştir. ${ }^{34}$ Çünkü analojik akıl yürütme ile ilgili açıklamalarında en çok paradigma

\footnotetext{
${ }^{30}$ Govier'in U-Claim olarak nitelendirdiği ilkedir. Govier, "Analogies and Missing Premises," s.147.

${ }^{31}$ Govier, "Should A Priori Analogies Be Regarded as Deductive Arguments?," s.155.

32 Paradigmatik analoji formu, klasik mantık ve informel mantık çalışmalarındaki analoji yaklaşımlarından esinlenerek tarafımızca türetilmiş bir formdur. Bu sebeple açıklamalar her iki mantık sisteminin karşılaștırılması şeklindedir.

${ }^{33}$ Hamdi Ragıp Atademir, Aristo'nun Mantık ve İlim Anlayışı (Ankara: Ankara Üniversitesi İlahiyat Fakültesi Yayınları, 1974), s.146.

${ }^{34}$ Aristoteles'te paradigmatik analoji "misal yoluyla istidlal" olarak geçmektedir. Ancak görüldüğü gibi detaylı bir açıklama yapılmamış ve formu da verilmemiştir. Aristoteles'in paradigmayı kullandığı diğer eserlerinde de sadece tanım ve örnekler mevcut olup formuyla ilgili bir ibare bulunmamaktadır.
} 
kelimesini kullanmıştır. Örneğin Birinci Analitikler'de Aristoteles paradigmayı şu şekilde açıllar:

Büyük ucun, üçüncü terime benzer bir terimle orta terime ait olduğu ispat edildiği zaman misal vardır. Ama orta terimin üçüncü terime, birincinin üçüncüye benzer terime ait olduğunun bilinmesi gerekir. Söz gelimi, A nın kötü, B nin komşulara savaş açmak, G nin Thebaililer'e karşı Atinalılar, D nin de Phokisliler'e karşı Thebaililer demek olduğunu kabul edelim. Thebailer'e savaş açmanın bir kötülük olduğunu ispat etmek istersek komşularına savaş açmanın bir kötülük olduğunu kabul etmek gerekir. Bu son önermeye inanç, benzer hallerden; söz gelimi, Thebailer için Phokisliler'e savaş açmanın kötü olduğundan çıkar. Mademki komşulara savaş açmak bir kötülüktür ve Thebailer'e karşı savaş komşulara karşı savaş açmaktır, şu hâlde Thebailer'e savaş açmanın bir kötülük olduğu açıktır. Şimdi, B nin, G ye ve D ye ait olduğu, apaçık bir şeydir (çünkü her iki halde de bu, komşulara savaş açmaktır); A nın D ye ait olduğu da açıktır. (Çünkü Phokisler'e karşı savaş Thebailer için hayırlı olmadı). A nın, B ye ait olduğu, D de ispat olunacaktır. Orta terimin uçla olan münasebetinin ispatı birçok benzer hallerle elde edilmişse, ispat yine aynı tarzda yapılacaktır. 0 halde misal yoluyla istidlalin ne bölümden bütüne, ne bütünden bölüme giden istidlal olmayıp, bunun aksine olarak iki hususî hal, aynı tümele tabi olduğu ve bunlardan biri bilindiği zaman, bölümden bölüme bir istidlal olduğu görülüyor. Misal yoluyla istidlalin endüksiyondan farkl, endüksiyonun bütün fertlerden hareket ederek büyük ucun orta terime ait olduğunu ispat etmesi ve kıyası küçük uca tatbik etmemesidir, hâlbuki misal bu tatbiki yapar ve bütün fertlerden hareket ederek ispat etmez. ${ }^{35}$

Bu örneği Bartha şekil 2'deki gibi sembolleştirmiştir:36

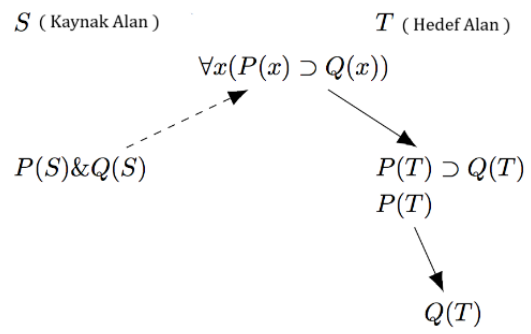

Şekil 2. Bartha'nın Analoji Şeması (2013)

Aristoteles, burada $\mathrm{x}, \mathrm{y}, \mathrm{z}$ gibi birçok benzerlikten değil, tek bir

\footnotetext{
${ }^{35}$ Aristotle, Prior Analytics, 68b40-69a5-15.

${ }^{36}$ Paul Bartha, "Analogy and Analogical Reasoning," The Stanford Encyclopedia of Philosophy, (Spring 2019 Edition), https://plato.stanford.edu/archives/spr2019/entries/reasoning-analogy/ (10.04.2021)
} 
benzerlikten yola çıkarak paradigmatik analoji kullanmıştır. Dolayısıyla kullandığı form şu şekildedir:

1. A, x özelliğine sahiptir.

2. B de $x$ özelliğine sahiptir.

3. x özelliğine sahip olan her șey f özelliğine de sahiptir. (gizli tümel önerme)

4. Dolayısıyla B de f özelliğine sahiptir.

Verilen örneği bu forma uygularsak:

A: Kötü

B: Komşulara savaş açmak

G: Thebaililer'e Atinalılar'ın açtığı savaş

D: Phokisliler'e Thebaililer'in açtı̆̆ı savaş

1. Thebaililer Atinalılar'la komşudur ve onlara savaş açmaması gerekir.

2. Phokisliler de Thebaililer'le komşudur.

3. Komşulara savaş açmak kötüdür. (gizli tümel önerme)

4. Dolayısıyla Phokisliler de Thebaililer'e savaş açmamalıdır. (Burada G ve D'nin A olduğu B ile onaylanmaktadır.

Aristoteles'in örneklem olarak da kullandığı paradigma terimi için Retorik'te şöyle bir açıklaması vardır ki burada da indüksiyondan ve dedüksiyondan farklı; ama onların vasıtasıyla elde edilen bir çıkarımdan bahsetmektedir: "Örneğe dayandırılan örtük tasımlar bir ya da birbirine benzer daha çok sayıda indüksiyonla ilerleyen ve genel bir önermeye ulaşan, daha sonra bir dedüksiyonla özel bir çıkarıma giderek tartışllanlardır." ${ }^{37}$ Bunu şekil 3'teki gibi bir șema ${ }^{38}$ ile gösterebiliriz:

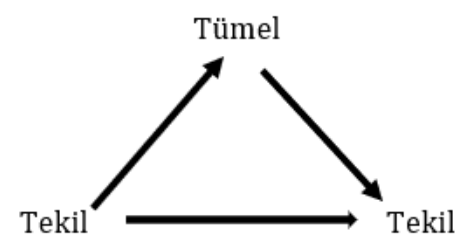

Şekil 3. Paradigmatik Analojinin Oluşum Şeması

Aristoteles'in paradigma ile aynı anlamda kullandığı örneklemin, delil ve şahit olmak üzere iki derecesi ${ }^{39}$, gerçek ve kurgusal olmak üzere iki türü

\footnotetext{
${ }^{37}$ Aristoteles, Retorik, 1402b15.

38 Paradigmatik analoji șeması tarafımızca olușturulmuștur.

39 Abdulkadir Coşkun, "İbn Sina'da Retorik" (Yayımlanmamış Doktora Tezi, Marmara Üniversitesi, İstanbul, 2010), s.155.
} 
vardır. ${ }^{40}$ Gerçek örneklem, geçmiş gerçek olaylardan elde edilir. ${ }^{41}$ Kurgusal örneklemin de iki türü vardır. Bunlar betimleyici koşut ve hayvan masallarıdır. ${ }^{42}$ Aristoteles Retorik'te tüm bu türleri ayrı ayrı örnekler vererek açıklamıştır.43 Dolayısıyla Aristoteles paradigmatik analoji formu olarak adlandırdığımız bu formu retorik bir unsur olarak kullanmıştır. Aristoteles'ten sonraki klasik mantık savunucularının çoğu da paradigmatik analojiyi yani misal yoluyla istidlali detaylandırmamış, olduğu gibi aktarmıştır. Ancak özellikle informel mantık alanında analoji ile ilgili artan çalışmalar ışığında, aslında Aristoteles'in ele aldığı bu analoji türünün hem formel hem de içeriksel anlamda ciddi varyasyonları olabileceği kanaatindeyiz.

İnformel mantık alanında analojinin indüktif mi, dedüktif mi yoksa a priori mi olduğuyla ilgili tartışmalar çerçevesinde paradigmatik analojiye ilişkin iddiamız paradigmatik analojinin, indüktif ve dedüktif analoji formlarından farklı, ikisinin birleşiminden oluşan bir form olduğudur. Çünkü paradigmatik analojide zihin, indüktif şekilde ilerler ve sonuca dedüktif yolla ulaşır. Diğer bir deyişle indüksiyonla tümel önermeye ilerleyip, dedüksiyonla tümel önermeden tekrar tekile gider. Böylece tekilden yine tekilin elde edildiği analojik akıl yürütme elde edilir. Burada paradigmatik analojinin formunu verip, daha sonra diğer iki formdan farkını açılayabiliriz.

1. A; $x, y, z$ ve f özelliklerine sahiptir.

2. B de $x, y$, z özelliklerine sahiptir.

3. * $\mathrm{x}, \mathrm{y}, \mathrm{z}$ özelliklerine sahip olan her şey f özelliğine de sahiptir. (gizli tümel önerme)

4. Dolayısıyla, B de f özelliğine sahiptir.

Öncelikle indüktif analojinin $\mathrm{x}, \mathrm{y}$, z gibi birçok özellikten hareket edip bu özelliklerin $\mathrm{f}$ ile olan ilişkisini ortaya koyduğunu daha önce formel olarak belirttik. Bu form bariz bir şekilde dedüktif analoji formundan farklıdır. Genellikle fen bilimlerinde kullanılır. Örneğin; yeni keşfedilen bir tür bitkinin, eskiden bilinen bir bitki türüyle karșılaștırılıp yeni türde henüz rastlanmamış ancak eski türde bilinen bir özelliğin, yeni türde de muhtemelen olabileceğini varsayıp bu yönde araștırma yapmaya başlarken analojinin bu formu kullanılır. Dedüktif analojide ise A'nın sahip olduğu x

\footnotetext{
${ }^{40}$ Aristoteles, Retorik, 1393a25.

41 Aristoteles gerçek örneklem için sadece geçmişte yaşanan olayları esas almıştır; ancak İbn Sīnā şimdiki zamanda devam edenleri de ilave etmiștir. Coşkun, "İbn Sina'da Retorik," s.159.

42 Aristoteles, Retorik, 1393a25.

${ }^{43}$ Aristoteles, Retorik, 1393a25-30, 1393b5-30, $1394 a 5$.
} 
özelliği ile ilgili zihnimizde halihazırda varolan "x özelliğine sahip olan her şey f özelliğine de sahiptir." gizli önerme sayesinde, B ile ilgili hüküm çıkarılmaktadır. Her ne kadar informel mantık alanında analojinin bu formuyla ilgili çok fazla tartışma olsa da bize göre analojinin değersiz bir akıl yürütme tarzı olarak görülmesine sebep olan dedüktif analoji formudur. Çünkü bu form, tek bir özellikten yola çıkmakta ve dolayısıyla onun yanlışlanabilme ihtimali oldukça yüksek olmaktadır. Paradigmatik analoji formunda ise önce tekilin tek ya da birçok özelliğinden hareket ederek tümel elde edilir, sonra bu tümelden aynı özellikleri taşıyan başka bir tekile dedüksiyon yoluyla geçilir. Bu sebeple paradigmatik analoji, X'de bulunan bir özelliğin X'e benzer özellikler gösteren Y'de de olduğuna dair sezgisel bir dayanak sağlar. Dolayısıyla özellikle bilimsel teori üretmede sıklıkla kullanılır.

\subsubsection{Vaka Temelli Analoji Formu}

Vaka temelli analoji, yeni vakaları açıklamak için eski vakaların kullanılmasıdır. ${ }^{44}$ Burada önemli olan eski vakalardan elde edilen tecrübedir. Çünkü tecrübe yeni vakaları çözmek için araç olarak kullanılır. ${ }^{45}$ Vaka temelli analojide paradigmatik analojiden farklı olarak iki tekil bir tümel altında değil, doğrudan kendi aralarında karşılaştırılır. Aristoteles de benzerliğin bazı durumlarda indüksiyon gibi evrensele gitmediğini ancak evrensel önermeye ulaşmada bir adım olabileceğini ifade etmiştir. Dolayısıyla genellemelerden emin değilsek yapmamız gereken indüksiyon değil vaka temelli analojik akıl yürütmedir. ${ }^{46}$ Bunun dışında Aristoteles Topikler'de, benzerlik argümanının ne dereceye kadar bize yardımcı olabileceğini tartışmış, iki şey arasındaki benzerlik derecesi arttıkça sonucun doğru olma olasılığının da arttığını vurgulamıştır. ${ }^{47}$ Smith'in iddiasına göre Aristoteles, özellikle ampirik gözlemlerde, açılamalara ulaşmak için, diğer yöntemlerin yetersiz kaldığı durumlarda vaka temelli analojiye yönelir. Diğer bir deyișle ampirik verilerin elde edilmesinin imkânsız olduğu ya da gerçekleşme olasılığının olmadığı durumlar için, Aristoteles eldeki malzemeyi

\footnotetext{
${ }^{44}$ Meral Demirören, "Probleme Dayalı Öğrenme-Entegre Tıp Eğitimi Programında Öğrencilerin Klinik Akıl Yürütme Becerisinin Değerlendirilmesi" (Yayımlanmamış Yüksek Lisans Tezi, Ankara Üniversitesi, Ankara, 2008), s.17.

45 Janet Kolodner, Case-Based Reasoning (San Mateo: Morgan Kaufmann, 2014), s.4.

${ }^{46}$ Nathan L. Smith, "Explanation through Analogical Reasoning in Aristotle's Natural Science" (Senior Honors Thesis, University of North Carolina at Chapel Hill, Chapel Hill, 2015), ss.27-29.

${ }^{47}$ Bartha, "Analogy and Analogical Reasoning."
} 
sinıflandırır ve durumu benzerliğe dayalı bir şekilde açılklamaya çalışır. ${ }^{48}$

Atademir, paradigmatik analoji ile vaka temelli analojiyi birbirinden ayırarak ${ }^{49}$ vaka temelli analoji için "bir halden benzeri veya yakın başka bir hale geçmektir" tanımını kullanır. ${ }^{50}$ İzmirli İsmail Hakkı da Fenni Menāhic'de, indüksiyon ile analoji arasındaki farkı, vaka temelli analojinin bu özelliğine dayandırmaktadır.

İndüksiyonda, bir cinsin belli bir türünün bazı fertleri gözlemlenerek, o tür veya cins ile ilgili genelleme yapılır. Dolayısıyla indüksiyonda aynıdan aynıya doğru bir geçiş vardır. Ancak analojide sadece gözlemlenen fertlerin türü ile ilgili değil farklı türlerin fertleri ile ilgili de çıkarım yapılabilir. Yani analojide benzerden benzere bir geçiş vardır. $\mathrm{Bu}$ yönüyle indüksiyon ve analoji birbirinden ayrılır. Analojinin bu özelliğinden dolayı, sonucu kıyas ile desteklense de sonuç daima olumsal olarak kalır. ${ }^{51}$

Bu açıklamalardan da anlaşılacağı üzere vaka temelli analoji yapılırken bir halden başka bir hale, bir cinsten başka bir cinse, bir türden başka bir türe ve bir türün bir hassasından başka bir türün hassasına geçiş vardır. Analojinin bu formunda denetleyici bir mekanizma olarak genel/tümel ifade kullanılmaz. Bunun yerine benzerlik yapılırken, karşılaştırılan iki şeyin beş tümele göre durumu veya bazı ilkeler kullanılır. Beş tümele göre karşılaştırılma yapılıyorsa burada dikkat edilmesi gereken husus, bir cinsin türü ile başka bir cinsin türünün karşılaştırılmasıdır. Yani bir cinsin türü ile başka bir türün hassası karşılaştırılırsa yapılan bu akıl yürütmenin sonucu geçersiz olur.

Vaka temelli analoji formu, vakıa hukukunda (common law) emsal davalar hakkında karar vermek için kullanılır ve denetleyici mekanizma olarak da a priori ilkelere başvurulur. Hukuk metinlerinde vaka temelli analojinin mantıksal formu şu şekildedir:

Önerme 1: Ox'dir.

$\mathrm{x}$, bir emsal olgu ya da emsal olgular dizisini belirtir. 0 ise, $\mathrm{x}$ olgularından çıkan özel bir hukuki sonuç olarak düzenlenen hükmün gerekçesini ifade eder.

Önerme 2: Sxy'dir. (yani x ve y olgularının altında toplandığı S sonuç

\footnotetext{
${ }^{48}$ Smith, "Analogical Reasoning in Aristotle's Natural Science," s.3.

${ }^{49}$ Atademir, paradigmatik analoji için misal yoluyla istidlal, vaka temelli analoji için sadece analoji ifadesini kullanmaktadır.

${ }^{50}$ Atademir, Aristo'nun Mantık ve Illim Anlayışı, s.145.

51 İsmail Hakkı İzmirli, Fenn-i Menāhic (Dersaâdet: Hukuk Matbaası, 1329/1911), s.40.
} 
hükmü veya yüklemi)

Sxy, yeni olayın olguları (y) ile emsal olayın (x) olguları arasındaki benzerlikle (S) oluşmaktadır.

Önerme 3: "(Ox ^ Sxy) $\rightarrow$ Oy"dir.

(i) Eğer bir emsal karar, $x$ olgularının 0 hükmüne bağlanması ile düzenlenmişse,

(ii) Eğer x olguları y olguları ile $S$ hükmünde (yükleminde) benzerlik gösteriyorsa,

(iii) Hukuki sonuç olarak y olguları x olgularıyla aynı (S) hükme veya emsal karara sahip olması açısından, aynı (0) hükmünü içerir. ${ }^{52}$

İnformel mantık çalışmalarında vaka temelli analoji a priori analoji olarak kullanılmaktadır. Çünkü denetleyici mekanizma olarak kullanılan temel ilke a priori bir ilkedir. Vaka temelli analojiye New Jersey'de geçen bir vapur davasından örnek verebiliriz. Davada, vapurdaki bir yolcunun seyahat masrafları için bulundurduğu paranın, kendi ihmali olmaksızın gece kamarasından çalınması durumunda taşıyıcının bundan sorumlu olduğuna karar verilmiştir. Yargıç bu karara, vaka temelli analoji kullanarak hancıların sorumluluğundan ${ }^{53}$ yola çıkarak ulaşmıştır. Ona göre vapura 'yüzen han' adı verilebilir. ${ }^{54}$ Yargıcın savunması şu şekildedir:

İki olay, aynı değilse bile, birbirine o kadar yakın benzerlikler taşır ki, aynı sorumluluk kuralının geçerli olması gerekir. Bu nedenle, davalının, davacının çalınan parayla ilgili herhangi bir ihmal kanıtı olmaksızın, usulüne uygun olarak sorumlu tutulduğu kanaatindeyiz..$^{55}$

Olayla ilgili verilen kararın kısa formülü şudur: (i) Bir otel (han) konuğu, kişisel kullanım için bir oda satın alır. Konuğun parası ve kişisel eşyaları, mal sahibinin onları çalabilmesine son derece açıtıtır. (ii) Bir vapur yolcusu, kişisel kullanım için bir oda satın alır. Yolcunun parası ve kişisel eşyaları, mal sahibinin onları çalabilmesine son derece açıktır. (iii) Bir otel sahibinin, konuğun eşyaları ile ilgili önemli bir sorumluluğu vardır, öyle ki, misafirin odasından para çalınırsa, ihmal kanıtı olmaksızın otel sahibi sorumludur.

\footnotetext{
52 Fuat Altuntaş, “Hukukta Akıl Yürütme Yöntemi Olarak Kıyas (Analoji)” (Yayımlanmamış Yüksek Lisans Tezi, Erzincan Binali Ylldırım Üniversitesi, Erzincan, 2020), s.67; Katja Langenbucher, "Argument by Analogy in European Law," The Cambridge Law Journal 57:3 (1998), s.493.

${ }^{53}$ Daha önceki bir davada, handa çalınan paradan hancılar sorumlu tutulmuştur ve bu davada emsal olay olarak kullanılmıştır.

${ }^{54}$ Burada kullanılan genel ilkeye göre sorumluluğu altındaki şeyden kişi mesuldür.

55 Adams v. New Jersey Steamboat Co., 151 N.Y. 163, 45 N.E. 369. Martin Golding, "Argument by Analogy in The Law," Hendrik Kaptein ve Bastiaan van der Velden (ed.) Analogy and Exemplary Reasoning in Legal Discourse (Amsterdam: Amsterdam University Press, 2018) içinde s.125.
} 
(iv) Malikin bu kadar katı bir sorumluluğa sahip olmasının nedeni, konuğun eşyalarının malik tarafından çalınabilme ihtimalinin yüksek olmasıdır. (v) Bu nedenle, yolcu odasından para çalınırsa, vapurun sahibi, ihmal kanıtı olmaksızın sorumludur. ${ }^{56}$

Vaka temelli bir analojinin sonucunu kabul edersek aslında, bir özelliğin birincil özneye ait olacağını veya ait olabileceğini tahmin etmeyiz. Aksine, birincil konuyu bir şekilde tanımlamaya çalışıyoruzdur. Vaka temelli analojilerin temeli, benzer olayların uygun șekilde benzer yollarla ele alınmasıdır. Bu tür analojilerin esası, analog durum hakkındaki ampirik gözlemlerin doğruluğuna bağlı değildir ve sonuç, ampirik gözlemle kesin olarak doğrulanabilecek veya yanlışlanabilecek bir sonuç değildir. ${ }^{57}$ Konuyla ilgili doktora tezinde Jerome Bickenbach buna "yansıtıcı akıl yürütme" adını vermiştir ve onun "vakalardan" ya da "vakaya göre" olduğunu söylemiștir. ${ }^{58}$

Vaka temelli analoji ile paradigmatik analoji arasındaki fark, vaka temelli analojide, analoğun gerçek bir durum olmasına gerek olmamasıdır. Analog tamamen varsayımsal veya hayal ürünü de olabilir. ${ }^{59}$ Çünkü vaka temelli analojide amaç iki şeyin öncülleri arasındaki benzerlik ilişkisi değil sonuç ilişkisidir. Diğer bir deyişle hüküm benzerliğidir. Bunu, şekil 4'teki gibi bir tabloyla gösterebiliriz: ${ }^{60}$

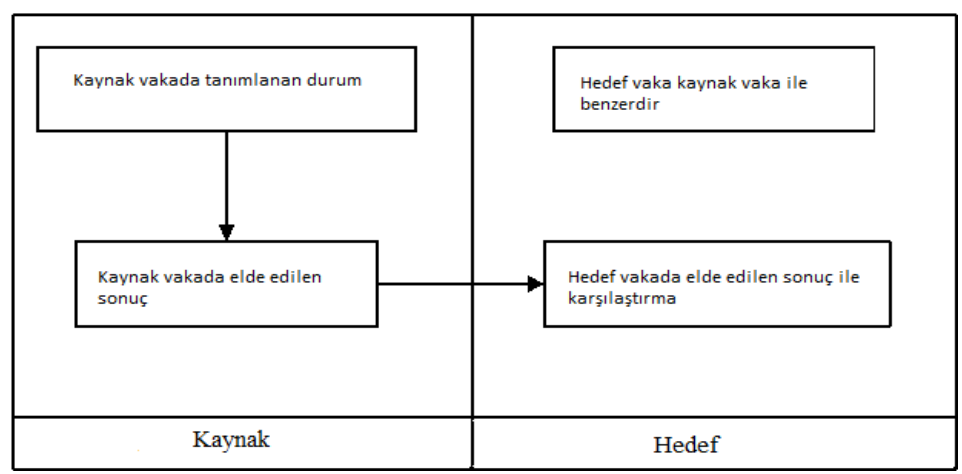

Şekil 4. Vaka Temelli Analoji Şeması

Burada ilk olarak, sonuç olarak belirli bir ifadeyi önermek için makul görünen bir kaynak vaka sunulur. Ardından, kaynak vakaya benzer bir hedef

\footnotetext{
${ }^{56}$ Golding, "Argument by Analogy in The Law," s.125.

57 Govier, "Analogies and Missing Premises," s.143.

58 Jerome Edmund Bickenbach, "The Nature and Scope of Reflective Reasoning" (Yayımlanmamış Doktora Tezi, University of Alberta, 1977).

${ }^{59}$ Govier, "Analogies and Missing Premises," s.142.

60 Tabloda kaynak durumdan hedef duruma sonuç transferi yapılmıştır. Douglas Walton, "Story Similarity in Arguments from Analogy," Informal Logic 32:2 (2012), s.193
} 
vaka sunulur. Bu çıkarımda analojinin amacı, hedef vakada da aynı sonuca veya paralel sonuca ulaşmaktır. Diğer bir deyişle hedef vaka kaynak vakaya benzer olduğundan, kaynak vakada belirli bir sonuç çıkarıldığında, eş zamanlı olarak hedef vakada da benzer sonuç çıkarılır. ${ }^{61}$

Deneyim vaka temelli analojide çok önemli bir unsurdur. Burada analoji için deneyimin önemini vurgulamak adına tıp alanında analoji kullanımına bakabiliriz. Çünkü tıbbi teşhis ve tedavide genellikle bu tür analojik akıl yürütme kullanılır. Bir hasta, farklı teşhisleri düşündüren çelişkili semptomlar gösterebilir. Ya da tıbbi durumu birkaç farklı hastalığı ve dolayısıyla farklı tedavi yöntemini içeriyor olabilir. Örneğin hastalığının biri için bir terapi türü uygunken; bir diğeri için aynı tedavinin tersi uygun olabilir. Burada doktorun görevi, hastanın önemli olan hastalığını daha az önemli olandan ayırt etmektir. Bunu yaparken de doktorun benzer vakalarla ilgili deneyim birikimi ve bu deneyimiyle doğru çıkarımda bulunabilmesi, genellikle teşhis ve faydalı bir tedavi için çok önemlidir. ${ }^{62}$

Daha önce de belirttiğimiz gibi vaka temelli analojide iki vaka karşılaştırılırken; her ikisinin de her zaman gerçek vaka olmasına gerek yoktur. Burada önemli olan kaynak vakanın sonucunun hedef vakanın sonucunu desteklemesi ve iki durumun hükümleri arasındaki transferdir. Diğer bir deyişle vaka temelli analojik bir akıl yürütmede, iki (veya daha fazla) vakanın birbirinin analogları olduğu belirlendiğinde ve her ikisi de aynı mantıksal formu paylaştıklarında biri için verilen hüküm diğeri için de verilebilir. ${ }^{63}$ İnformel mantık geleneğinde çok kullanılan kemancı örneğini, burada konunun daha iyi anlaşılması için kullanabiliriz. Kemancı örneği, Thomson tarafından "tecavüz sonucu oluşan hamilelikte kürtaja izin verilebilir" iddiasını savunmak için kullanılan meşhur bir argüman vakasıdır. Vaka şu şekildedir:

Sabah uyanıyorsunuz ve kendinizi bilinçsiz ünlü bir kemancı ile sırt sırta buluyorsunuz. Bu kemancının ölümcül bir böbrek rahatsızlığı olduğu tespit edilmiştir. Müzik Severler Derneği, tüm mevcut tıbbi kayıtları incelemiş ve yardım edebilecek tek kişinin siz olduğunuzu çünkü sadece sizin uygun kan grubuna sahip olduğunuzu bulmuştur. Bu nedenle sizi kaçırmışlar ve dün gece kemancının dolaşım sistemi sizinkine takılmıștır. Böylelikle böbrekleriniz hem onun kanından hem de sizin kanınızdan zehirleri çıkarmak için kullanılabilir hale gelmiştir. Hastanenin müdürü şimdi size şunu söylüyor, "Bakın, Müzik Severler

\footnotetext{
${ }^{61}$ Walton, "Story Similarity in Arguments from Analogy," s.194.

${ }^{62}$ Evelyn M. Barker, "Beardsley's Theory of Analogy," Informal Logic 11: 3 (1989), s.190.

63 John Woods ve Brent Hudak, "By Parity of Reasoning," Informal Logic 11:3 (1989), s.133.
} 
Derneği bunu size yaptığı için üzgünüz, bilseydik buna asla izin vermezdik. Ama yine de yaptılar ve kemancı şimdi size bağll. Fişini çıkarmak onu öldürmek olur. Ama eğer fişi çıkarmazsanız, bu durum sadece dokuz ay sürecek ve kemancı o zamana kadar rahatsızlığından kurtulmuş olacak. Dolayısıyla o zaman geldiğinde güvenli bir şekilde sizden ayrılabilir. 64

$\mathrm{Bu}$ varsayımsal vaka bir katılımcıya sunulduğunda; kişi muhtemelen kemancıya bağlanan kişinin, fişi çekme hakkına sahip olduğu sonucunu çıkaracaktır. Tartışmanın dayanağı, kemancının diğer kişinin vücudunu kullanma hakkına sahip olmadığı varsayımıdır ve ortaya çıkan sonuç, kişinin fişini çekerken o kişinin yaşam hakkını ihlal etmediğidir. Bir aktarım süreciyle, bu durumda kullanılan argüman, benzer bir şekilde kürtaj vakasına uygulanabilir. Bu gerekçeyle, tecavüz sonucu hamile kalan bir kadının, sonuç olarak fetüs ölecek olsa bile, gebeliğini sonlandırma hakkına sahip olduğu ileri sürülmektedir. Nedeni, kemancının fişini çekip çekmeyeceğine karar veren kişinin kaynak davasının kürtaj yapıp yapmamaya karar veren kadının hedef davasına benzer olduğu varsayımına dayanmaktadır. Analojik argümanın amaçlanan sonucu, kürtajın, fetüsün yaşam hakkını ihlal etmeyeceği, sadece fetüsü hamile kadının vücudunun kullanımından mahrum bırakacağıdır. Tıpkı kemancı vakasında olduğu gibi, fetüsün de kadının vücudunu kullanma hakkı yoktur, dolayısıyla tecavüz sonucundaki kürtaj durumunda, fetüs kadının vücudundan çıkarılabilir. ${ }^{65}$

Burada kullanılan analojinin amacı iki vakayı birbirine bağlayan benzerliği tanımlamak ve kaynak vakanın, hedef vakanın sonucunu desteklemek için makul bir argüman olarak kullanılmasını sağlamaktır. ${ }^{66} \mathrm{Bu}$ amaca, kaynak vaka ile hedef vakanın hikaye adı verilen belirli bir yapıyı nasıl paylaştığını aşağıdaki aşamalar gösterilerek ulaşılır: ${ }^{67}$

1. Kişi kendini ünlü kemancının yanında bulur.

2. Kişinin bu düzenleme konusunda seçeneği yoktur.

3. Kemancının bağlı olması kişiye bir yüktür.

4. Kemancının kişiye bağlanması, kişinin günlük aktivitelerini

\footnotetext{
${ }^{64}$ Judith Jarvis Thomson, "In Defense of Abortion," Philosophy and Public Affairs 1:1 (1971), ss.48-49.

65 Thomson, "In Defense of Abortion," s.50.

${ }^{66}$ Walton, "Story Similarity in Arguments from Analogy," s.195.

${ }^{67} \mathrm{Bu}$ aşamalar Walton'ın makalesinden alıntılanmıștır. Walton, "Story Similarity in Arguments from Analogy," ss.199-203.
} 
engelleyecektir.

5. Kemancının fişi kişiden çıkarılırsa kemancı ölür.

6. Kemancı ancak kişiye bağlı olarak dokuz ay yaşayabilir.

7. Kişi kemancının kendisinden ayrılması konusunda seçim yapabilir.

Henüz bir sonuç çıkarılmadı. Çünkü, yukarıdaki yedi ifade dizisi sadece, birinin vakadaki hikayeyi tanımasını sağlayan bağlantılı bir olaylar dizisini temsil eder. Yöntemdeki bir sonraki adım, hedef vakadaki karşılaştırılabilir hikayeyi belirlemektir:

1. Tecavüze uğrayan kadın kendini hamile bulur.

2. Kadının hamile kalma konusunda hiçbir seçeneği yoktur.

3. Hamile olmak kadın için bir engeldir.

4. Hamile olmak kadının günlük aktivitelerini engelleyecektir.

5. Kadından çıkarılırsa fetüs ölür.

6. Fetüs ancak yaklaşık dokuz aylık bir süreye kadar kadın tarafından taşınırsa hayatta kalabilir.

7. Kadın fetüsü aldırma konusunda seçim yapabilir.

Hikaye, kaynak vakada ve hedef vakada belirlendikten sonra, iki vakayı birbirine bağlayan analojik argümanın, benzerlik öncülünün temeli analiz edilebilir. Analojik argümanı analiz etme yöntemindeki bir sonraki adım, her iki hikaye için ortak olan hikaye şemasının ifade edildiği daha yüksek bir soyutlama seviyesine ilerlemektir. Bu hikaye şeması aşağıdaki gibi, sıralı bir şekilde oluşturulabilir: ( $\mathrm{z}$ kişisi, $\mathrm{x}$ 'in herhangi bir seçeneği olmadan vücuduna başka bir y kişisini bağladı; y'nin eklenmiş olması, x'in günlük faaliyetlerini sekteye uğratacak bir engeldir; $\mathrm{x}$ ve $\mathrm{y}$, $\mathrm{x}$ 'ten çıkarıldığında $\mathrm{y}$

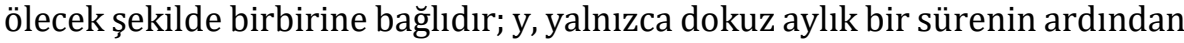
x'ten çıkarıldığında hayatta kalabilir; x, y'nin kaldırılıp kaldırılmayacağı konusunda bir seçim yapabilir). Analojiden gelen bu özel argüman için hikaye şeması, aşağıda şekil 5'te metin kutularındaki açık cümlelerin değişkenler içerdiği şekildeki yapı ile temsil edilebilir. Bu kutulardaki ifade işlevleri, ilgili öyküdeki ifadelerin soyutlamalarıdır. Ok, metin kutularını birleştiren, ilgili öyküdeki ifade çiftleri arasındaki farklı türdeki ilişkileri temsil etmektedir. Genellikle bir olaydan önce meydana gelen bir şeyin açıklamalarını veya öykü dizisinde bir yeri olduktan sonra meydana gelen bir şeyi temsil eder. Bu hikaye şeması hem kaynak vaka hem de hedef vaka için geçerli olan soyut bir yapı sunar. Kaynak vakadaki hikayeden çıkarılan sonuç, kemancının bağlı olduğu kişinin onu çıkarmayı seçme hakkına sahip olması gerektiği fikrini ortaya çıkarmak için tasarlanmıştır. Analojiden elde edilen sonuç argümanı da tecavüz nedeniyle hamile kalan bir kadının, kürtaj 
yaptırıp yaptırmamayı seçme hakkına sahip olması gerektiğidir.68

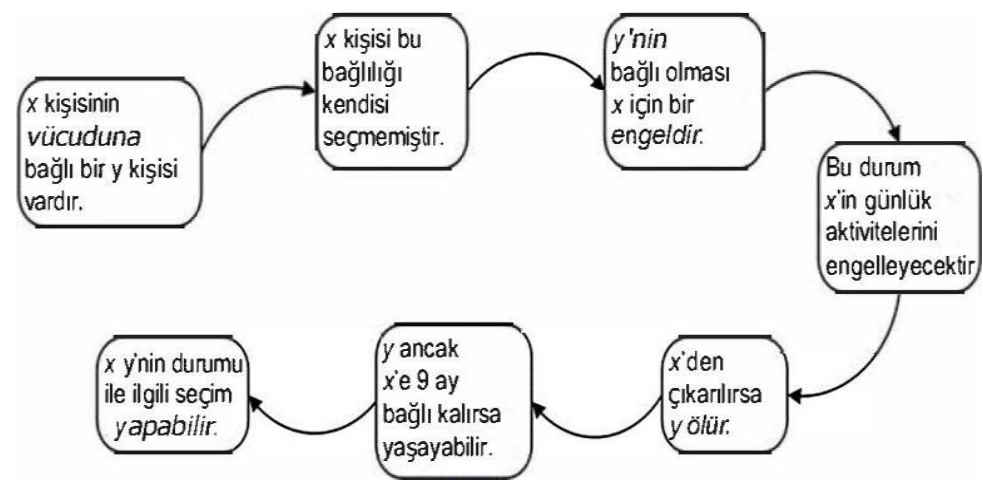

Şekil 5. Kemancı Vakasında Hikaye Şemasının Doğrusal Ağaç Yapısı

Thomson'ın analojisi, kürtaj için güçlü bir savunma sağlar; çünkü tecavüz sonucu oluşan hamilelik, bir kadının hayatına istem dışı bir saldırı ve onurunun ihlalidir. Bu durumda kürtaj tercihi ise, kişinin bireysel haklarını vurgulayan ahlaki bir durumdur. ${ }^{69}$

İki vaka için ortak olan ve kaynak vakadan hedef vakaya kadar olan argümanı mantıklı kılan iki vaka arasındaki benzerliğin temeli olan hikaye şemasını belirledikten sonra, benzerliğin temelinin kavranmasıdır. $\mathrm{Bu}$ şemada analojik akıl yürütmenin sonucu, üç nedenden ötürü güçlüdür. Birincisi, hem kaynak vaka hem de hedef vaka hikaye şemasına uyar. İkincisi, hikaye şeması, her iki vakaya da uyan düzenli bir sırayla, bir dizi ortak öğeyi birbirine bağlar. Üçüncüsü, iki vakanın hikaye şemasına uyması, analojik argüman için argümantasyon şemasının, ilk önermesini destekler. Bu üç nedenden ötürü, kemancı vakası bize, desteklemek için ileri sürüldüğü sonucun lehine olan, güçlü bir analoji argümanı sunar. ${ }^{70}$

Vaka temelli analojinin Aristoteles ve informel mantık alanındaki kullanım alanlarına baktığımızda, iki sistemde farklı işlevde kullanıldığını söyleyebiliriz. Çünkü Aristoteles vaka temelli analojiyi açıklama mekanizması olarak kullanmaktadır. Ancak informel mantık geleneğinde vaka temelli analoji; hukuk alanında olduğu gibi kanıtlama mekanizması olarak kullanılmaktadır. Bize göre her iki sistemde farklı işlevde kullanılan vaka temelli analojinin, paradigmatik ve orantı analojisinden farklı bir form

\footnotetext{
68 Walton, "Story Similarity in Arguments from Analogy," s.200.

${ }^{69}$ Barker, "Beardsley's Theory of Analogy," s.192.

70 Walton, "Story Similarity in Arguments from Analogy," s.201.
} 
olarak ele alınması mümkündür.

\subsubsection{Orantısal Analoji Formu}

Orantısal analojide dört nesnenin birbiriyle olan ilişkisi söz konusudur. $\mathrm{Bu}$ tür analojide esas olan, orantılanan iki nesnenin birbirleriyle olan ilişkisiyle, diğer ikisinin de aynı (veya benzer) bir ilişkiye sahip olmasıdır. Yani orantı analojisi diğer analojilerden farklı olarak, ilişkideki benzerlik esasına dayanır. Bu ilişki, tek bir özniteliğe, bir öznitelikler kompleksine veya sıralı bir öznitelik çiftine dayanabilir. Örneğin, filin fareyi boy olarak aşması gibi, tavşan da kaplumbağayı hız bakımından aşar. Orantılı analoji farklı durumların altında yatan ortak bir ilkeye odaklanır. ${ }^{71}$

Aristoteles, Nikomakhos'a Etik'te orantı analojisini şu şekilde açıklamıştır:

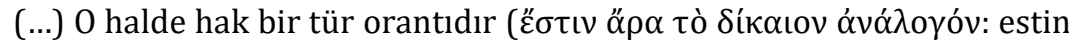
ara to dikaion analogon). Çünkü orantı yalnızca birimlerden oluşan sayıların bir özelliği değil, genel olarak sayının özelliğidir; nitekim oranlamada oranların eşitliği ve en az dört şey söz konusudur. Çünkü bölünmüş ortalamada dört şeyin söz konusu olduğu açık, ama sürekli olanında da dört şey vardır, çünkü bir terimi ikiymiş gibi kullanır, yani onu iki kez ifade eder. Örneğin "a" nın "b" ile ilişsisi nasılsa, "b"nin de "c" ile ilişkisi öyledir. Demek ki "b"den iki kez söz edilmiştir. Öyleyse "b" iki

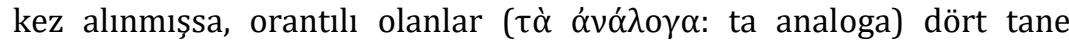
olacaktır. Hatta en az dört şey söz konusudur ve oran aynıdır; çünkü aynı şekilde iki kişiye ve iki şeye bölünür (...). Matematikçiler de bu oranlamaya geometrik orantı adını verirler. Nitekim geometrik orantıda teklerden birinin diğeri ile ilişkisi ne ise, bütün ile bütünün ilişsisi de odur (...). 0 halde bu hak orantılı olandır; haksızlık da orantılı olana

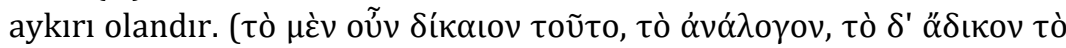

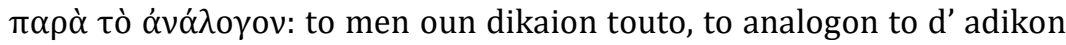
to para to analogon $)^{72}$

Aristoteles'in bu açıklamasını en basit şekliyle A:B::C:D şeklinde ifade edebiliriz. $.^{73} \mathrm{~A}, \mathrm{~B}, \mathrm{C}$, D dört farklı kavram olmak üzere; A bir tanım, A:B ise bir önermedir. Aynı şekilde $C$ bir tanım, C:D ise bir önermedir. A ve B kavramları arasında kurulan ilişki, C ve D kavramları arasında kurulan ilişkiye

\footnotetext{
${ }^{71}$ Brown, "Two Traditions of Analogy," s.162.

72 Aristoteles, Nikomakhos'a Etik, 1131a25-1131b5; Ali Tekin, "Meşşâî Mantıkta Örneklemenin (Analoji) Farklı Cihetlerden İncelenmesi Üzerine Bir Soruşturma," Bingöl Üniversitesi Sosyal Bilimler Enstitüsü Dergisi 9: Özel Sayı (2019), s.345.

${ }^{73}$ Karen A. Pierce, Barry Gholson, "Surface Similarity and Relational Similarity in the Development of Analogical Problem Solving: Isomorphic and Nonisomorphic Transfer," Developmental Psychology 30:5 (1994), s.724.
} 
benzerdir. Aristoteles bu benzerliği; "benzerliklerin eşitliği ya da eşitliklerin benzerliği" olarak tanımlamıştır. ${ }^{74}$ Çünkü orantısal argümanlar üzerinden tanımlanan orantı analoji ilişkisi simetriktir. Simetriklik özelliği sadece orantı analojisine mahsus bir özelliktir. ${ }^{75}$ Diğer analoji türleri simetrik değildir. ${ }^{76}$ Orantı analojisinin simetriklik özelliği şu aksiyomlara dayanır:

- Bir şeye eşit olan iki şey, birbirine eşittir.

- Eşit olan ögelere, eşit miktarlar eklenirse bu ögeler yine eşit olur.

- Eşit olan ögelerden, eşit miktarlar çlkarılırsa bu ögeler yine eşit olur.

- Birbirleriyle çakışan şeyler, birbirine eşittir.77

Ayrıca Aristoteles Poetika' da orantı analojisini ad aktarmasını açıklarken metaforik ${ }^{78}$ bir araç olarak da kullanmıştır:

(1) cinsin anlamının türe verilmesi (apo tou genous epi eidos/ $\alpha$ тó tov

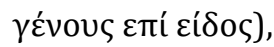

(2) türün anlamının cinse verilmesi (apo tou eidous epi to genos/ $\alpha$ đó

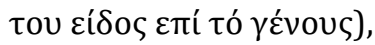

(3) bir türün anlamının bir başka türe verilmesi ile (apo tou eidous epi

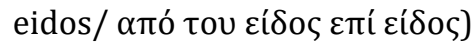

yahut da son olarak

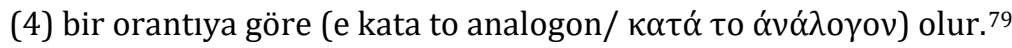

$\mathrm{Bu}$ açıklamadan bazı araştırmacılar, Aristoteles'in orantı analojisini, metaforun basit bir versiyonu olarak kabul ettiği anlamını çıkarmaktadır. ${ }^{80}$ Ancak bizce Aristoteles'in burada bahsettiği orantı analojisi değil, orantılı metafordur.

Brown, orantı analojisine şöyle bir örnek vermektedir:

Porsche: Volkswagen:: Cadillac: Chevrolet

$$
\frac{\text { Porsche }}{\text { Volkswagen }}=\frac{\text { Cadillac: }}{\text { Chevrolet }} \quad / \frac{\mathrm{A}}{B}=\frac{C}{D}
$$

Porsche hız olarak Volkswagen'i aşarken, Cadillac da lükslük bakımından

\footnotetext{
74 Usha Goswami, "Analogical Reasoning: What Develops? A Review of Research and Theory," Child Development 62:1 (1991), s.2.

${ }^{75}$ Orantısal analojinin simetriklik özelliği matematiksel analojide kesin sonuçlar elde edilmesine sebep olurken, kavramsal ilişkiler söz konusu olduğunda, tamamen varsayımsal sonuç verir.

${ }^{76}$ John Woods, Brent Hudak, "By Parity of Reasoning," s.127.

77 Bu maddeler Öklid'in eșitlik aksiyomlarıdır.

${ }^{78}$ Aristoteles'e göre metafor 'ad' kategorisine ait bir türdür ve "bir adın yabancı bir șeye aktarılması" demektir. Aristoteles, Poetika, 1457b1. İnformel mantıkta metafor, figüratif analoji olarak geçmektedir.

${ }_{79}$ Aristoteles, Poetika, $1457 \mathrm{~b} 5$.

${ }^{80}$ Brown, "Two Traditions of Analogy," s.164.
} 
Chevrolet'i geçer.

Görüldüğü üzere orantı analojisi dört terim arasındaki benzerlik ilişkisine dayanmaktadır. Ancak bu ilişkide Porsche ve Cadillac'ın ortak bir özelliği olduğu söylenmez. Farklı üreticiler tarafından üretilen, Araba A ve Araba C, yine farklı üreticiler tarafından üretilen Araba B ve Araba D'den daha pahalı olma özelliğine sahipse, o zaman Araba A ve Araba C de muhtemelen sirasiyla Araba B ve Araba D'den daha yüksek kalitededir diyebiliriz. Buradaki ilke hızlı olma ile pahalı olmanın birbirine paralel olmasıdır. Ancak bu çok da sağlıklı bir çıkarım değildir. Çünkü A ve $C$ arabaları asla aynı otomobille karşılaştırılmasa da her ikisi de aynı açıdan başka bir otomobille karşılaştırılmıștır. ${ }^{81}$

Bu örneğin değişik bir versiyonunu paradigmatik analoji ile gösterirsek, orantı analojisi ile paradigmatik analoji arasındaki farkı daha net anlayabiliriz.

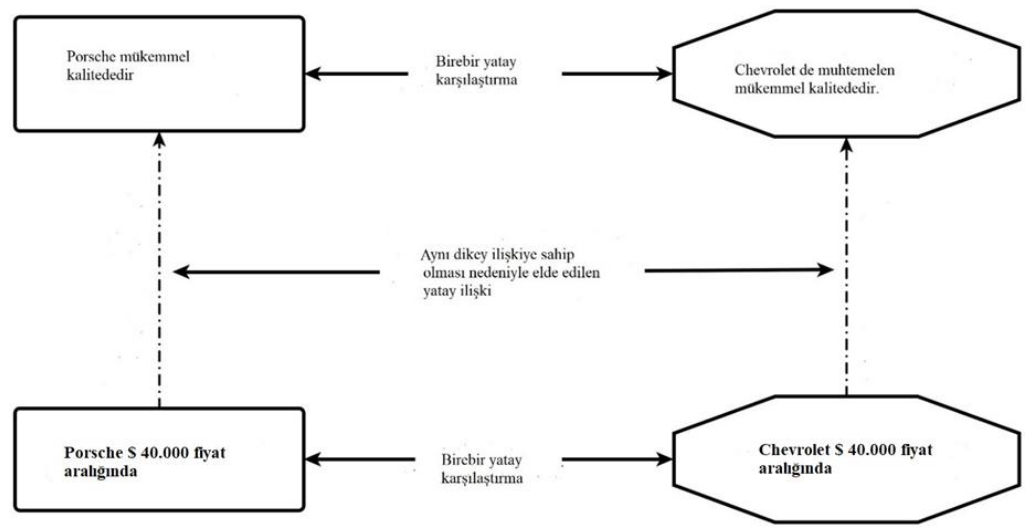

Şekil 6. Paradigmatik Analojinin Şekilsel Örneği

1. Porsche $\$ 40.000$ civarındadır.

2. Chevrolet de $\$ 40.000$ civarındadır.

3. Porsche mükemmel kalitededir.

4. $\$ 40.000$ civarında olan her araba mükemmel kalitededir. (Bu öncül örtük bir şekilde zihinde mevcuttur.)

5. Dolayısıyla muhtemelen Chevrolet de mükemmel kalitededir.

Paradigmatik analoji, tahmin edilmesi gereken bir șeye, yani belirli bir nesnenin belirli bir özelliğine odaklanır. Orantılı analoji ise, farklı durumların

${ }^{81}$ Brown, "Two Traditions of Analogy," s.163. 
altında yatan ortak bir ilkeye odaklanır.

Matematiksel ilimlerde analojinin orantısal formu kullanılır. Dolayısıyla elde edilen sonuç kesin ve zorunludur. Sayısal analojiye örnek vermek gerekirse, 2/4, 4/8, 8/16 gibi kesirler arasındaki yarımlık ilişkisini ele alabiliriz. Görüldüğü gibi örnekte verilen sayılar hep aynı değere eşit olma bağlamında birbirlerine benzemektedirler. Burada 16/? gibi bir soruyla karşılaşsak hemen ortak illet olan yarımlık ilişkisiyle analoji yaparak cevabın 32 olması gerektiğini buluruz. Burada yapılan akıl yürütme, üç bilinen sayıdan ortak illet vasıtasıyla dördüncü sayıyı bulmaktır. Görüldüğü gibi bu analoji türünün sonucu zannî değil kesin ve zorunludur. ${ }^{82}$

Matematiksel orantı analojisinin iki türü vardır. Bunlardan birincisi aritmetik oran, ikincisi geometrik orandır. ${ }^{83}$

\section{Aritmetik Analoji}

Aritmetik oran $(12-8=7-3=4)$

\section{Geometrik Analoji}

Geometrik oran $(3 / 6=12 / 24=1 / 2)$

Analojik akıl yürütmenin matematiksel oran versiyonu genellikle SAT ve IQ gibi zekâ testlerinin oluşturulmasında kullanılmıştır. Çünkü benzerlikleri ve farklılıkları tanıyabilme yeteneği birçok zeka testinin vazgeçilmez bir metodudur.

\section{Sonuç}

Türkçe literatürde hakkında çok fazla çalışma bulunmayan analojik akıl yürütme, son zamanlarda informel mantık alanında çok tartışılan bir konu haline gelmiştir. Bu tartışmadaki en önemli konular, farklı türde analojik akıl yürütme formlarının olup olmadığı ile ilgilidir. Biz de informel mantık alanındaki çalışmalara ek olarak, öncelikle analojik akıl yürütmenin doğrudan ve dolaylı formlarını ortaya koymaya çalıștık. Bunu yaparken de çalışmamızı informel geleneğe ek olarak Aristoteles'in çalışmalarına dayanarak temellendirmeye çalıştık. Ayrıca daha iyi bir analiz sağlaması için, analojinin formel ve içeriksel şablonunu oluşturduk.

Çalışmanın sonucunda, Aristoteles mantığında olumsal sonucu nedeniyle hakkında çok fazla bilgi bulunmayan analojik akıl yürütme ile ilgili aslında Aristoteles'in eserlerine dayanarak farklı okumaların yapılabileceği

82 Muhammed Âbid el-Câbirî, Arap İslam Kültürünün Akıl Yapısı: Arap-İslam Kültüründeki Bilgi Sistemlerinin Eleştirel Bir Analizi, terc. Hasan Hacak, Burhan Köroğlu, Ekrem Demirli (İstanbul: Kitabevi Yayınları, 2001), s.476.

${ }^{83}$ Gülümser Durhan, Aristoteles ve Platon'da Analoji (İstanbul: Çizgi Kitabevi, 2020), s.70. 
çıkarılmıştır. Ayrıca informel mantık çalışmalarında genellikle iki türü bulunan analojik akıl yürütmenin esasında üç farklı formda ele alınabilmesinin mümkün olduğu görülmüştür. Bu çlkarımlara ek olarak; çalışmada temellendirmeye çalıştığımız dolaylı analoji formlarının, iki şey arasındaki benzerlik ilişkisini farklı yollardan elde ettikleri söylenebilir. $\mathrm{Bu}$ farkları șu şekilde sıralayabiliriz: 1) Paradigmatik analoji benzerliği gizli tümel önerme çatısı altında iki tekilin karşılaştırılması şeklinde yaparken, vaka temelli analoji ve orantı analojisi bu karşılaştırmayı a priori bir ilkeye göre yapmaktadır. 2) Vaka temelli analojide nedensel faktör önemliyken paradigmatik analojide amaçsal faktör önemlidir. 3) Orantı analojisinde diğerlerinden farklı olarak (diğerlerinde iki tekil karşılaştırılır) dört tane tekil bulunmakta ve tekiller arasındaki ilişki orantısal olarak karşılaştırılmaktadır.

Yine bu üç form işlev açısından da farklıdır. Bu işlevler şunlardır: 1) Paradigmatik analojinin sezgisel bir işlevi vardır. Yani bir nesnenin sahip olduğu bazı özelliklerden, bu nesne başka açılardan bir diğerine benzer olduğunda, diğer nesne ile benzerliğinin olası varlığını öngörmekten ibarettir. Psikolojik çıkarımların temelinde analojinin bu işlevi yoğun bir şekilde kullanılır. Özellikle günlük hayatta, yeni karşılaşılan şeylerin tanıdık hale getirilmesinde sezgisel bir yol izlenir. Aynı zamanda bilimsel buluşlarda da analojinin sezgisel gücünden faydalanır. 2) Vaka temelli analojinin tartışmacı bir işlevi vardır. Yani bir şeyin başka bir şeye benzerliği temelinde, yeni bir olaya veya olay ile ilgili verilen hükme atfedilen bir özelliğin, sağlam delillerle eski olayda da olduğunu kanıtlamayı amaçlar. Hukuki çıkarımlarda analoji kullanıldığında, genellikle analojinin bu işlevi ön plandadır. 3) Orantı analojisinin hem didaktik işlevi hem de matematiksel bir işlevi vardır. Didaktik işlevi, iletişimsel veya pedagojik bir amacı yerine getirmek için bazı karmaşık fenomenlerin gerçekçi veya şiirsel basit bir çağrıştırıcı görüntüsünü sağlamayı amaçlar. Matematiksel işlevi ise matematiksel işlemlerin orantısal çözümünde, problem çözme mekanizması olarak kullanilır.

Sonuç olarak bu çalışma, tartışılan analoji formlarına alternatif bir çözüm olarak, üç farklı dolaylı analoji formu ve hatta metaforlar da dahil olmak üzere dolaysız akıl yürütme formlarının da dahil olduğu, geniş bir analoji yelpazesinde, analojiyi çeşitli çıkarım türlerini içeren, karmaşık bir çıkarım dizisi olarak ortaya koymaktadır. 
Çıkar Çatışması / Conflict of Interest:

Finansal Destek / Grant Support:
Yazar, çıkar çatışması olmadı̆̆ını beyan etmiştir. / The author declared that there is no conflict of interest.

Yazar, bu çalışma için finansal destek almadığını beyan etmiștir. / The author declared that this study has received no financial support.

\section{KAYNAKÇA}

Altuntaş, Fuat. "Hukukta Akıl Yürütme Yöntemi Olarak Kıyas (Analoji)," Yayımlanmamış Yüksek Lisans tezi, Erzincan Binali Yıldırım Üniversitesi, Erzincan, 2020.

Alvargonzález, David. "Proposal of a Classification of Analogies," Informal Logic 40:1 (2020), ss.109-137.

Aristotle. Rhetorica Ad Alexandrum. Terc. H. Rackham, Cambridge: Harvard University Press, 1957.

Aristotle. Topica. Terc. E. S. Forster, Cambridge: Harvard University Press, 1960.

Aristotle. Posterior Analytics. Terc. Hugh Tredennick, Cambridge: Harvard University Press, 1960.

Aristoteles. Prior Analytics. Terc. Hugh Tredennick, Cambridge: Harvard University Press, 1962.

Aristoteles. Retorik. Terc. Mehmet H. Doğan, İstanbul: Yapı Kredi Yayınları, 1995.

Aristoteles. Nikomakhos'a Etik. Terc. Furkan Akderin, İstanbul: Say Yayınları, 2014.

Aristoteles. Metafizik. Terc. Y. Gurur Sev, İstanbul: Pinhan Yayıncılı, 2018.

Aristoteles. Poetika. Terc. Ari Çokona, Ömer Aygün, İstanbul: Türkiye İş Bankası Yayınları, 2020.

Atademir, Hamdi Ragıp. Aristo'nun Mantık ve İlim Anlayıșı. Ankara: Ankara Üniversitesi İlahiyat Fakültesi Yayınları, 1974.

Barker, Evelyn M. “Beardsley's Theory of Analogy,” Informal Logic 11:3 (1989), ss.185-194.

Bartha, Paul. "Analogy and Analogical Reasoning," The Stanford Encyclopedia of Philosophy (Spring 2019 Edition), https://plato.stanford.edu/archives/spr2019/entries/reasoning-analogy/ (10.04.2021)

Bermejo-Luque, Lilian. "A Unitary Schema for Arguments by Analogy," Informal Logic 32:1 (2012), ss.1-24.

Bickenbach, Jerome Edmund. "The Nature and Scope of Reflective Reasoning," Yayımlanmamış Doktora Tezi, University of Alberta, 1977.

Botting, David. "The Paradox of Analogy," Informal Logic 32:1 (2012), ss.98-115.

Brown, William R. "Two Traditions of Analogy,” Informal Logic 11:3 (1989), ss.161172. 
el-Câbirî, Muhammed Âbid. Arap İslam Kültürünün Akıl Yapısl: Arap-İslam Kültüründeki Bilgi Sistemlerinin Eleștirel Bir Analizi. Terc. Hasan Hacak, Burhan Köroğlu, Ekrem Demirli, İstanbul: Kitabevi Yayınları, 2001.

Coşkun, Abdulkadir. “İbn Sina'da Retorik,” Yayımlanmamış Doktora Tezi, Marmara Üniversitesi, İstanbul, 2010.

Çelik, Zeynep. "Bir Akıl Yürütme Yöntemi Olarak Analojinin Değeri,” Yayımlanmamış Doktora tezi, Ankara Üniversitesi, Ankara, 2021.

Demirören, Meral. "Probleme Dayalı Öğrenme-Entegre Tıp Eğitimi Programında Öğrencilerin Klinik Akıl Yürütme Becerisinin Değerlendirilmesi," Yayımlanmamış Yüksek Lisans Tezi, Ankara Üniversitesi, Ankara, 2008.

Duit, Reinders. “On the Role of Analogies and Metaphors in Learning Science," Science Education 75:6 (1991), ss.649-672.

Durhan, Gülümser. Aristoteles ve Platon'da Analoji. İstanbul: Çizgi Kitabevi, 2020.

Emiroğlu, İbrahim. Mantık Yanlışları. Ankara: Elis, 2011.

Golding, Martin. "Argument by Analogy in the Law," Hendrik Kaptein ve Bastiaan van der Velden (ed.) Analogy and Exemplary Reasoning in Legal Discourse (Amsterdam: Amsterdam University Press, 2018) içinde, ss.123-136.

Goswami, Usha. "Analogical Reasoning: What Develops? A Review of Research and Theory," Child Development 62:1 (1991), ss.1-22.

Govier, Trudy. “Analogies and Missing Premises," Informal Logic 11:3 (1989), ss.141152.

Govier, Trudy. "Should a Priori Analogies Be Regarded as Deductive Arguments?" Informal Logic 22:2 (2002), ss.155-157.

İmamoğlugil, Halil. Klasik Mantıkta Akıl Yürütme. Ankara: Araştırma Yayınları, 2018.

İnönü, Nazlı. "Yeni Bir Çıkarım Türü: Geriçıkarım," Yayımlanmamış Doktora Tezi, İstanbul Üniversitesi, İstanbul, 2006.

İzmirli, İsmail Hakkı. Fenn-i Menāhic. Dersaâdet: Hukuk Matbaası, 1329/1911.

Juthe, Andre. "Analogical Argument Schemes and Complex Argument Structure," Informal Logic 35: 3 (2015), ss.378-445.

Kamer, Vedat. "İnformel Mantık Açısından 'Akılyürütme' Kavramı Üzerine Bir Araştırma," Yayımlanmamış Doktora Tezi, İstanbul Üniversitesi, İstanbul, 2014.

Kamer, Vedat. "Feshedilebilir Akılyürütme,” Vedat Kamer ve Şafak Ural (ed.), VI. Mantık Çalıștayı Kitabı (İstanbul:Mantık Derneği Yayınları, 2016) içinde, ss.245-254.

Kamer, Vedat. "Aristoteles ve İnformel Mantık," Mehmet Mahfuz Söylemez, Recep Duran (ed.) 2400'üncü Yılında Aristoteles ve Aristoteles'in Dünya Tefekküründeki Yeri (Lefkoşa: Yakın Doğu Üniversitesi Yayınları, 2017) içinde, ss.235-250.

Kolodner, Janet. Case-Based Reasoning. San Mateo: Morgan Kaufmann, 2014.

Kraus, Manfred. "Arguments by Analogy (and What We Can Learn About Them from Aristotle)," Bart Garssen ve Frans H. van Eemeren (ed.), Reflections on Theoretical Issues in Argumentation Theory (Switzerland: Springer, 2015) içinde, ss.171-182. 
Langenbucher, Katja. "Argument by Analogy in European Law," The Cambridge Law Journal (1998), ss.481-521.

Öner, Necati. Klasik Mantık. Ankara: Ankara Üniversitesi Basımevi, 1986.

Piaget, Jean. Çocukta Dil ve Düşünme. Ankara: Palme Yayıncılık, 2017.

Pierce, Karen A., Barry Gholson. "Surface Similarity and Relational Similarity in the Development of Analogical Problem Solving: Isomorphic and Nonisomorphic Transfer," Developmental Psychology 30:5 (1994), ss.724-737.

Shecaira, Fábio Perin. "Analogical Arguments in Ethics and Law: A Defence of a Deductivist Analysis," Informal Logic 33 (2013), ss.406-437.

Smith, Nathan L. "Explanation through Analogical Reasoning in Aristotle's Natural Science," Senior Honors Thesis, University of North Carolina at Chapel Hill, Chapel Hill, 2015.

Şen, Zekai. Modern Mantık. İstanbul: Bilge Kültür Sanat, 2003.

Tekin, Ali. "Meşşâî Mantıkta Örneklemenin (Analoji) Farklı Cihetlerden İncelenmesi Üzerine Bir Soruşturma," Bingöl Üniversitesi Sosyal Bilimler Enstitüsü Dergisi 9: Özel Sayı (2019), ss.339-362.

Thomson, Judith Jarvis. "In Defense of Abortion," Philosophy and Public Affairs 1:1 (1971), ss.47-66.

Waller, Bruce N. “Classifying and Analyzing Analogies,” Informal Logic 21:3 (2001), ss.199-218.

Walton, Douglas. "Story Similarity in Arguments from Analogy," Informal Logic 32:2 (2012), ss.190-221.

Woods, John, Brent Hudak. "By Parity of Reasoning," Informal Logic 11: 3 (1989), ss.125-139. 
